Journal of Southeast Asian

\title{
[Special Issue on Hmong Newcomers to Saint Paul Public Schools] Introduction
}

Bic Ngo

University of Minnesota, bcngo@umn.edu

Follow this and additional works at: https://docs.lib.purdue.edu/jsaaea

Part of the Education Commons

\section{Recommended Citation}

Ngo, Bic (2008) "[Special Issue on Hmong Newcomers to Saint Paul Public Schools] Introduction," Journal of Southeast Asian American Education and Advancement: Vol. 3 : Iss. 1, Article 1.

DOI: $10.7771 / 2153-8999.1097$

Available at: https://docs.lib.purdue.edu/jsaaea/vol3/iss1/1

This document has been made available through Purdue e-Pubs, a service of the Purdue University Libraries. Please contact epubs@purdue.edu for additional information.

This is an Open Access journal. This means that it uses a funding model that does not charge readers or their institutions for access. Readers may freely read, download, copy, distribute, print, search, or link to the full texts of articles. This journal is covered under the CC BY-NC-ND license. 


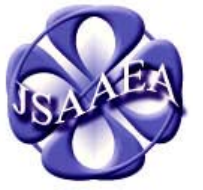

Volume 3 (2008)

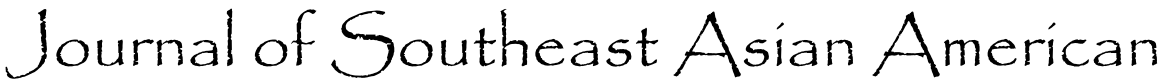

Education \& Advancement

WWW.JSAAEA.org
A peer-reviewed

scholarly journal

published by the

National Association

for the Education \&

Advancement of

Cambodian, Laotian, and Vietnamese Americans (NAFEA)

\title{
Introduction Special Issue on Hmong Newcomers to Saint Paul Public Schools
}

\author{
Guest Editor \\ Bic Ngo \\ University of Minnesota
}

In the late 1970s the aftermath of the Vietnam War brought displaced Hmong refugees (along with other Southeast Asian groups) to the United States (Chan, 1994; Long, 1993). Other waves of Hmong resettlement to the United States occurred in the mid-80s and mid-90s. This has resulted in a Hmong population of 183,265, the majority of whom reside in California, Minnesota, Wisconsin, Michigan and Colorado (U.S. Census Bureau, 2005). In 2004, the Thai government closed Wat Tham Krabok (WTK), the last of its Hmong refugee camps (Grigoleit, 2006). This resulted in the most recent resettlement of approximately 15,000 Hmong refugees to the United States (Grigoleit, 2006; Hang et al., 2004). An estimated 5,000 of these WTK refugees came to St. Paul, Minnesota (Hang et al., 2004).

To a large extent, St. Paul was well-prepared to receive the Hmong refugees, since the St. Paul-Minneapolis metropolitan area was already home to the largest urban concentration of Hmong in the world (Minneapolis Foundation, 1999). A resettlement assessment task force put together by then St. Paul mayor Randy Kelly also provided city, county, and community members with information about the educational, social service, and physical and mental health needs of the new refugees (Hang et al., 2004). The assessment report provided information about Hmong families that were of special interest to educators. Among other things, it revealed that children 14 years old or younger comprised more than half (52\%) of the population; and less than half of these children had experience with formal schools (Hang et al., 2004). Similar to the WTK Hmong children, Hmong adults also had exceptionally limited experience with education (Hang et al., 2004).

To prepare for the arrival of approximately 1,000 school-age children to the Saint Paul Public Schools (SPPS), district personnel assessed the capacity of its English Language Learner (ELL) programs to meet the language and educational needs of WTK families. The district determined that it needed to invest in a language program specifically for the newcomer Hmong population. Transitional Language Centers (TLCs) were thus established to provide short-term, intensive language programs offering bilingual instruction in Hmong and English. From the beginning, the TLCs were designed to be temporary programs that would rapidly transition K-6 Hmong students to mainstream schools and programs.

During the 2004-2005 academic year TLCs were established in four elementary schools as well as one TLC for older youth in an academy for middle and high school students. TLC

\section{@)}

SOMERIGHISRESERNEDReaders are free to copy, display, and distribute this article, as long as the work is attributed to the author(s) and the Journal of Southeast Asian American Education \& Advancement, it is distributed for noncommercial purposes only, and no alteration or transformation is made in the work. More details of this Creative Commons license are available at http://creativecommons.org/licenses/by-nc-nd/3.0/. All other uses must be approved by the author(s) or JSAAEA. 
teachers and staff were provided "additional training in ELL strategies, Hmong culture, and refugee issues” by the school district (Saint Paul Public Schools, 2004). All newcomer Hmong students took an initial language assessment test at the district's Student Placement Center. The families were then able to choose between enrolling their children in a regular school program or a TLC program. Despite encouragement by the district to enroll their children in a TLC, refugee Hmong parents did not always choose the TLC. Instead, some chose more traditional ELL programs or Language Academy (LA) schools.

To determine the effectiveness of the TLC programs, Saint Paul Public Schools asked the Center for Applied Research and Educational Improvement (CAREI) at the University of Minnesota to conduct an evaluation study (see Bigelow et al., 2005). The multi-part study specifically examined the effectiveness of the newly created TLC programs with the established Language Academy programs. The primary questions for the larger study include: a) What are the perceptions of educators and parents of the capacity of the TLC and LA programs to meet the needs of elementary Hmong newcomers?; b) What, if any, are the differences between the programs in terms of students' language learning achievement?; and c) If there are differences, are the differences sufficient to warrant the extra costs associated with TLCs?

This special issue draws from this larger research study to examine the experiences and perspectives of three groups who were involved in and affected by the TLCs. The three articles in this issue on the transition of Wat Tham Krabok Hmong refugees to Saint Paul Public Schools reflect the experiences of "stakeholder" groups that include principals, teachers, and Hmong parents. Bigelow, Basford, and Smidt's article illustrate the perspectives of teachers and educational assistants on how well the TLCs and Language Academies supported the needs of the refugee children. Wahlstrom's article offers insights from the school principals at elementary schools that received WTK children. Ngo's article explores the experiences of WTK parents with their children's education, arguing for a need for more research on the affective consequences of cultural capital.

These articles provide insight into the experiences of the most recent generation of Hmong immigrants to the United States. They contribute to the growing research on Hmong American education (see, e.g., Ngo \& Lee, 2007), and attest to the need for practices, policies, and research that attend to the specific needs of different immigrant groups.

\section{References}

Bigelow, M., Ngo, B., Wahlstrom, K. L., Ingram, D., \& Whitehouse, B. (2005). A preliminary report on an evaluation of the transitional language center program in the Saint Paul Public Schools. Minneapolis:Center for Applied Research and Educational Improvement, College of Education and Human Development, University of Minnesota.

Chan, S. (Ed.). (1994). Hmong means free: Life in Laos and America. Philadelphia: Temple University.

Grigoleit, G. (2006). Coming home: The integration of Hmong refugees from Wat Tham Krabok, Thailand into American society. Hmong Studies Journal, 7, 1-22.

Hang, M., Anderson, J., Walker, P., Thao, M., Chang, M., \& Hestness, L. (2004). American Paj Ntaub: Wat Tham Krabok team assessment report executive summary. St. Paul, MN: City of St. Paul.

Long, L. D. (1993). Ban Vinai: The refugee camp. New York: Columbia University. 
Ngo, B., \& Lee, S. (2007). Complicating the image of model minority success: A review of Southeast Asian American education. Review of Educational Research, 77(4), 415-453.

Saint Paul Public Schools. (2004). St. Paul Public Schools to open two new transitional language centers. St. Paul, MN: Author. Retrieved October 16, 2008 from http://www.stpaul.k12. mn.us/15Nov2004.html

The Minneapolis Foundation (1999, Fall). Minnesota, nice or not? Minneapolis, MN: Author U.S. Census Bureau (2005). American Community Survey. Retrieved October 16, 2008 from http://factfinder.census.gov/servlet/DatasetMainPageServlet?_program=ACS\&_submenu

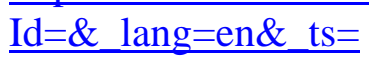


Ngo: Introduction

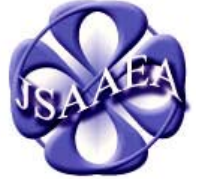

Volume 3 (2008)

\section{Journal of Southeast Asian American}

\section{Education \& Advancement}

WwW.JSAAEA.org
A peer-reviewed

scholarly journal published by the

National Association

for the Education \&

Advancement of

Cambodian, Laotian,

and Vietnamese

Americans (NAFEA)

\title{
Editor
}

Dr. Wayne E. Wright

University of Texas, San Antonio

Associate Editors

Dr. Chhany Sak-Humphry

University of Hawaii

Dr. KimOanh Nguyen-Lam

California State University, Long Beach

Book Review Editor

Vichet Chhuon

University of California-Santa Barbara

Creative Works Editor

Phouang Hamilton

Washington Office of Superintendent of Public Instruction

Special Advisor

Anne Frank

University of California, Irvine, Southeast Asian Archives

\author{
Editorial Assistant \\ Mariana Kuhl \\ University of Texas, San Antonio
}

Comments and questions for the editorial staff may be directed to jsaaea@lists.sis.utsa.edu

\section{Editorial Review Board}

\author{
Dr. Carl L. Bankston III \\ Tulane University \\ Dr. Phala Chea \\ Lowell Public Schools \\ Dr. Changming Duan \\ University of Missouri, Kansas City \\ Dr. Nancy H. Hornberger \\ University of Pennsylvania \\ Dr. Peter Nien-Chu Kiang \\ University of Massachusetts, Boston
}

\author{
Dr. Pollie Bith-Melander \\ Asian and Pacific Islander Wellness Center \\ Dr. George Chigas \\ University of Massachusetts, Lowell \\ Dr. Sophal Ear \\ U.S. Naval Postgraduate School \\ Dr. Samlong Inthaly \\ Minneapolis Public Schools \\ Dr. Kevin K. Kumashiro \\ University of Illinois, Chicago
}


Ngo: [Special Issue on Hmong Newcomers to Saint Paul Public Schools] I

Ngo: Introduction

\author{
Dr. Stacey Lee \\ University of Wisconsin, Madison \\ Dr. Sue Needham \\ California State University, Dominguez Hills \\ Dr. Max Niedzwiecki \\ Daylight Consulting Group \\ Dr. Clara Park \\ California State University, Northridge \\ Dr. Loan T. Phan \\ University of New Hampshire \\ Dr. Karen Quintiliani \\ California State University, Long Beach \\ Dr. Fay Shin \\ California State University, Long Beach \\ Dr. Yer J. Thao \\ Portland State University \\ Dr. Khatharya Um \\ University of California, Berkeley \\ Dr. Terrence G. Wiley \\ Arizona State University
}

Dr. David Chanpannha Ley

Montgomery County Public Schools

Dr. Bic Ngo

University of Wisconsin-Madison

Dr. Leakhena Nou
California State University, Long Beach
Dr. Mark Pfeifer
Texas A\&M University, Corpus Christi
Dr. Bounlieng Phommasouvanh
Minnesota Department of Education
Dr. Kalyani Rai
University of Wisconsin, Milwaukee
Dr. Nancy J. Smith-Hefner
Boston University
Dr. Myluong Tran
San Diego State University
Dr. Linda Trinh Vo
University of California, Irvine
Dr. Zha Blong Xiong
University of Minnesota

Dr. Leakhena Nou

Dr. Mark Pfeifer

Dr. Bounlieng Phommasouvanh

Dr. Kalyani Rai

Dr. Nancy J. Smith-Hefner

Boston University

San Diego State University

Dr. Linda Trinh Vo

Dr. Zha Blong Xiong

University of Minnesota

Dr. Kou Yang

California State University, Stanislaus

\section{Doctoral Student Editorial Review Board}

Keo Chea

University of Pennsylvania

Loan Dao

University of California, Berkeley

Ha Lam

Arizona State University

Vanna Som

Harvard University

Giang Pham

University of Minnesota

Tinou Tran

University of Houston, Texas

Phitsamay Sychitkokhong Uy

Harvard University
Vichet Chhuon

University of California, Santa Barbara

Annie BichLoan Duong

San Joaquin County Office of Education

Ravy Lao

University of California, Santa Barbara

Rassamichanh Souryasack

University of California, Santa Barbara

Layheng Ting

State University of New York, Albany

\section{Loan Tran}

University of California, Santa Barbara

Yang Sao Xiong

University of California, Los Angeles 